\title{
Development and validation of a Xanthomonas axonopodis pv. citri DNA microarray platform (XACarray) generated from the shotgun libraries previously used in the sequencing of this bacterial genome
}

\author{
Leandro M Moreira*1,2,3, Marcelo L de Laia4,5, Robson F de Souza ${ }^{3}$, Paulo A Zaini³ ${ }^{3}$ Ana CR da Silva 6 , Aline M da Silva ${ }^{3}$
} and Jesus A Ferro 5

\begin{abstract}
Background: From shotgun libraries used for the genomic sequencing of the phytopathogenic bacterium Xanthomonas axonopodis pv. citri (XAC), clones that were representative of the largest possible number of coding sequences (CDSs) were selected to create a DNA microarray platform on glass slides (XACarray). The creation of the XACarray allowed for the establishment of a tool that is capable of providing data for the analysis of global genome expression in this organism.
\end{abstract}

Findings: The inserts from the selected clones were amplified by PCR with the universal oligonucleotide primers M13R and M13F. The obtained products were purified and fixed in duplicate on glass slides specific for use in DNA microarrays. The number of spots on the microarray totaled 6,144 and included 768 positive controls and 624 negative controls per slide. Validation of the platform was performed through hybridization of total DNA probes from XAC labeled with different fluorophores, Cy3 and Cy5. In this validation assay, $86 \%$ of all PCR products fixed on the glass slides were confirmed to present a hybridization signal greater than twice the standard deviation of the deviation of the global median signal-to-noise ration.

Conclusions: Our validation of the XACArray platform using DNA-DNA hybridization revealed that it can be used to evaluate the expression of 2,365 individual CDSs from all major functional categories, which corresponds to $52.7 \%$ of the annotated CDSs of the XAC genome. As a proof of concept, we used this platform in a previously work to verify the absence of genomic regions that could not be detected by sequencing in related strains of Xanthomonas.

\section{Findings}

Citrus canker, or cancrosis, is a disease that affects most species of the Citrus genus [1]. Its symptoms can be observed on leaves, fruits or branches and are characterized by small, pointed and spongy pustules that are surrounded by a chlorotic halo on both sides of the leaf. This halo tends to spread quickly through the tissue, increasing its diameter and becoming brownish or darker in

* Correspondence: Immorei@gmail.com

${ }^{1}$ Departamento de Ciências Biológicas (DECBI), Instituto de Ciências Exatas e Biológicas, Universidade Federal de Ouro Preto, Campus Morro do Cruzeiro, Ouro Preto, MG, Brazil

Full list of author information is available at the end of the article color with a rough and salient appearance [2]. The causal agent of cancrosis is the bacterium Xanthomonas axonopodis pv. citri (XAC) [3], more recently renamed as Xanthomonas citri subsp. citri $[4,5]$ whose genome was completely sequenced in 2002 [6] and compared with others organisms [6-8]. Data from this sequencing project revealed that the XAC genome contains a circular chromosome of 5.2 Mbp and two plasmids (33 and 64 $\mathrm{Kbp}$ ), containing a total of 4,489 coding regions [6].

To perform the complete sequencing of this phytopathogen, shotgun libraries containing 46,462 clones were created and distributed over approximately 500 96- 
well plates, representing $98 \%$ of the genome, with an estimated coverage of seven times its size [6]. The remaining $2 \%$ of the genome was sequenced using a cosmid library.

Upon completion of the sequencing project, the clones were stored with the expectation that they would be useful for future functional genomics studies. We here explore one of the possible applications of this library, namely the use of these clones to build a DNA microarray platform for use in studies of gene expression and genotyping [9]. Building on the data provided by the XAC genome project, this tool will enable the exploration of the physiological and biochemical machinery of this organism in distinct environmental situations, both in vitro and in vivo, thus providing clues to the working of Xanthomonas metabolism and the mechanisms of infection and disease.

\section{Clone selection from shotgun libraries}

The clones in the XAC sequencing libraries were generated from total bacterial DNA (chromosomal DNA + plasmid DNA) using shotgun methods [10] and cloning into the pUC18 vector. The number of clones totaled 46,462 with inserts ranging in size from 400 to $5,200 \mathrm{bp}$ (Figure 1AB) [6]. All of these clones were placed in 496 96-well plates, and stored at $-80^{\circ} \mathrm{C}$. In order to represent the CDSs in the XACarray, clones that included the largest fragments ( 0.4 to $3 \mathrm{Kbp})$ of each CDSs of interest were selected. However, not all of the CDSs were represented by clones that included a single open-reading frame (ORF). Actually, many CDSs were represented by clones that possessed inserts with parts of other CDSs or even whole CDSs. Thus, the selected clones were divided into four possible overlap types, considering the sequence segment of interest in relation to the insert as a whole: I) the CDS is completely represented within the insert and is surrounded on both sides by intergenic regions and/or other CDSs; II) the insert is an internal fragment of the corresponding CDS; III) part of the interested CDS flanking the left margin of the insert, or IV) part of the interested CDS flanking the right margin of the insert (Figure $1 C)$. Details of the relationship between the insert and CDS of interest are described in the results and are summarized in Table 1.

\section{Amplification, purification and identification of PCR products}

The selected clone inserts were amplified through PCR after DNA extraction by the boiling preparation technique [11]. The amplification reactions were performed with an initial denaturation at $95^{\circ} \mathrm{C}$ for 5 minutes, followed by 40 denaturing cycles at $95^{\circ} \mathrm{C}$ for 45 seconds, annealing at $50^{\circ} \mathrm{C}$ for 30 seconds and extension at $72^{\circ} \mathrm{C}$ for 1 minute in a final volume of $50 \mu \mathrm{L}$ of amplification solution containing $1.0 \mu \mathrm{L}$ boiling prep product, $1 \mathrm{U}$ Taq
DNA Polymerase ${ }^{\mathrm{Tm}}$ (Invitrogen), $40 \mathrm{mM}$ dNTPs (Invitrogen) and 10 pmols of each universal oligonucleotide M13 (forward 5'-GTTTTCCCAGTCACGAC-3' and reverse 5'-CAGGAAACAGCTATGAC-3'). In an attempt to increase the amount of the generated product, $1.0 \mu \mathrm{L}$ of the amplification reaction was added to new amplification solution with the same volume and concentration of reagents and submitted to the amplification protocol described above.

The amplification products were purified with Multiscreen Millipore $^{\mathrm{TM}}$ (cat. \# MAFB NOB 50) filters plates and diluted in $50 \mu \mathrm{L}$ of $10 \mathrm{mM}$ Tris $\mathrm{pH} 8.0$ directly into 96-well plates. The purification products were then manually combined in 8384 -well plates; one of these plates contained the hybridization controls (ScoreCard [12]).

In all steps, the PCR products were evaluated by electrophoresis in 1\% agarose gels stained with ethidium bromide [13]. Amplicon size and quantity were estimated by comparison to a molecular weight standard that was created specifically for this purpose (Figure 2A). This standard contained three DNA fragments of 1,697, 689 and 297 bp, respectively, with pre-determined concentrations. The standard was produced by cleavage of the pUC19 plasmid with the restriction enzymes HindIII, NdeI and ScaI, respectively, and was purified using a cesium chloride density gradient column [14]. This strategy allowed for comparative visual analysis of the sample concentrations in the gels, eliminating the need for individual quantification of each observed product.

To ensure that each amplified PCR product was in fact the clone selected for each CDS, an end of the insert in each of the clones was sequenced using the universal oligonucleotide primer M13R and the BigDye terminator v3 ${ }^{\mathrm{TM}}$ kit (Applied Biosystems). These sequences were then compared to the database of sequencing reads and the XAC genome using the BLASTn algorithm [15].

\section{Fixation of PCR products onto glass slides}

Equal volumes of DMSO were added to the purified PCR products in 384-well plates so that the final concentration was approximately 200 to $400 \mathrm{fmol} / \mu \mathrm{L}$ of DNA [16]. Afterwards, DNA was deposited onto Type 7 mirrored glass slides (Amersham Biosciences/GE Healthcare) using a robot (Generation III Microarrays Spotter ${ }^{\mathrm{TM}}$ Amersham Biosciences/GE Healthcare). This robot allowed for the deposition of up to 4,608 DNA samples that were organized into 12 subsets (subarrays) of 384 spots $(12 \times 32)$ (Figure $2 \mathrm{~A})$. The set of 3,072 probes, which corresponded to the products on the 384-well plates and included positive and negative controls, was placed in duplicate in the two longitudinal halves of the slide. The duplicates were called set A and set B, respectively, and constituted a technical replica on each slide (Figure 2A). After DNA deposition, the slides were sub- 
Table 1: Analysis of clone selection grouped according to the overlap models.

\begin{tabular}{cccc}
\hline Type of clones & Total of selected clones & $\begin{array}{c}\text { Average size of overlap } \\
\text { Insert/CDS }\end{array}$ & $\begin{array}{c}\text { Average size of non-overlap } \\
\text { Insert/CDS }\end{array}$ \\
\hline I & 2055 & 635 & 835 \\
II & 463 & 1121 & 0 \\
III & 827 & 822 & 418 \\
IV & 1124 & 726 & 481 \\
Total & $\mathbf{4 4 2 1}$ & $\mathbf{8 3 0 . 5}$ & $\mathbf{5 7 8}$ \\
\hline
\end{tabular}

Note that the average total of the CDS/insert overlap (a) is greater than the average of the non-overlap (b).

mitted to $50 \mathrm{~mJ}$ UV light, which promoted the fixation of the DNA onto the support. The slides were stored in desiccators (relative moisture $\sim 5 \%$ ), ready to be used for any experimental purpose.

\section{$X A C$ cultivation and DNA extraction}

The XAC 306 isolate was extracted from Citrus limonia L. Osbeck (rangpur lime)-infected leaves and stored in $30 \%$ glycerol at room temperature until use. The strain was sowed to reactivate its growth in NA solid medium (3 $\mathrm{g} / \mathrm{L}$ of meat extract, $5 / \mathrm{L} \mathrm{g}$ of peptone, $5 \mathrm{~g} / \mathrm{L}$ of sodium chloride, $15 \mathrm{~g} / \mathrm{L}$ of agar) and was incubated at $28^{\circ} \mathrm{C}$ for 48 hours. Samples of the reactivated strain were minced in $12 \mathrm{~mL}$ of NA liquid medium in 25-mL Falcon tubes and maintained under gentle agitation at $28^{\circ} \mathrm{C}$ for 48 hours. Appropriated antibiotic was used when necessary. After this period, the samples were centrifuged for 30 minutes at 3,000 $g$ at room temperature. The supernatant was discarded, and $12.5 \mathrm{~mL}$ of wash buffer $(10 \mathrm{mM}$ Tris- $\mathrm{HCl}, \mathrm{pH}$ 8.8, $3.0 \mathrm{mM} \mathrm{KCl}, 1.25 \mathrm{mM} \mathrm{NaCl}$ ) was added to the bacterial pellet. The samples were shaken vigorously using a vortex and then centrifuged for 15 minutes at 3,000 $g$ at room temperature. The bacterial pellet was resuspended again, now using $10 \mathrm{~mL}$ of D buffer $(25 \mathrm{mM}$ sodium citrate, $\mathrm{pH}$ 7.0, 5.0 g/L sarkosyl, $4 \mathrm{M}$ guanidine isothiocyanate), and incubated in a $65^{\circ} \mathrm{C}$ water bath for 1 hour to promote cell lysis. After the lysis step, $5.0 \mathrm{~mL}$ of P buffer (667 mM Tris- $\mathrm{HCl}, 833 \mathrm{mM} \mathrm{NaCl}, 83 \mathrm{mM}$ EDTA, $\mathrm{pH}$ 8.0) was added. The solution was shaken by inversion and centrifuged for 30 minutes at 3,000 $g$ at room temperature. Aliquots $(1.0 \mathrm{~mL})$ of the supernatant were transferred to tubes with a $2.0 \mathrm{~mL}$ capacity, $1.0 \mathrm{~mL}$ of isopropanol was added and the samples were kept at $20^{\circ} \mathrm{C}$. The samples were then homogenized by inversion and centrifuged for 45 minutes at $3,000 \mathrm{~g}$ at $4^{\circ} \mathrm{C}$. The DNA pellet was resuspended, washed twice with $70 \%$ ethanol to promote precipitation and centrifuged for 15 minutes at 3,000 g. Finally, the DNA pellet was resuspended in $200 \mu \mathrm{L}$ TE buffer (10 mM Tris- $\mathrm{HCl}$, pH 8.0, 0.1 mM EDTA) containing $1 \mu \mathrm{g} / \mathrm{mL}$ of RNaseA and incubated for 1 hour at $37^{\circ} \mathrm{C}$. The quality and concentration of the extracted DNA was evaluated on a $0.8 \%$ agarose gel stained with ethidium bromide [14]; the profile of the band obtained for the DNA samples was compared to a molecular weight standard with known sizes and concentrations (Figure 2A).

\section{Preparation of labeled DNA and microarray hybridization}

Double-stranded DNA labeled with fluorophore was produced by Cy3-dCTP or Cy5-dCTP ${ }^{\text {тм }}$ (Amersham Biosciences/GE Healthcare) incorporation during polymerization from $2 \mu \mathrm{g}$ XAC total DNA (chromosomal + plasmid) that had been fragmented through the shearing technique $(\sim 14$ times through a syringe with $8 \mathrm{~cm}$ and 18 gauge needles) [17]. The reaction was performed using $1 \mu \mathrm{L}$ of the DNA polymerase Klenow Fragment ${ }^{\mathrm{ma}}$ (Gibco) at a high concentration $(40 \mathrm{U} / \mu \mathrm{L})$ and $500 \mu \mathrm{g}$ of random nonamer primers [18]. Afterwards, the labeled DNA was purified with Multiscreen $^{\mathrm{mm}}$ filter plates (Millipore), and the total amount of incorporated fluorophore was indirectly quantified through absorbance detection at $550 \mathrm{~nm}$ for Cy3 and $650 \mathrm{~nm}$ for Cy5. To ensure accuracy in the analysis, equivalent quantities of fluorescent DNA were used in the microarray hybridizations, which were performed for 16 hours at $42^{\circ} \mathrm{C}$ in hybridization buffer (Amersham Biosciences/GE Healthcare) with 50\% formamide. According to protocols described previously by Koide and coauthors [18], after washing, the slides were dried by applying a jet of compressed nitrogen gas. Microarray data was aquired using a Generation III Scan$n^{\mathrm{na}}$ (Amersham Biosciences/GE Healthcare) in order to obtain images of each fluorescent channel, Cy3 and Cy5, for each of the microarray probes (Figure 2A).

\section{Detection, quantification and normalization of fluorescence signals}

After the microarrays were scanned, the crude signal intensity of the images was determined using Array Vision $6.0^{\text {ra }}$ software (Image Research/Molecular Dynamics). For each spot on the microarray, which represents a specific probe, the foreground and background intensity were measured.

Data preparation included subtraction of the local noise for each spot, and calculation of average fluorescece 

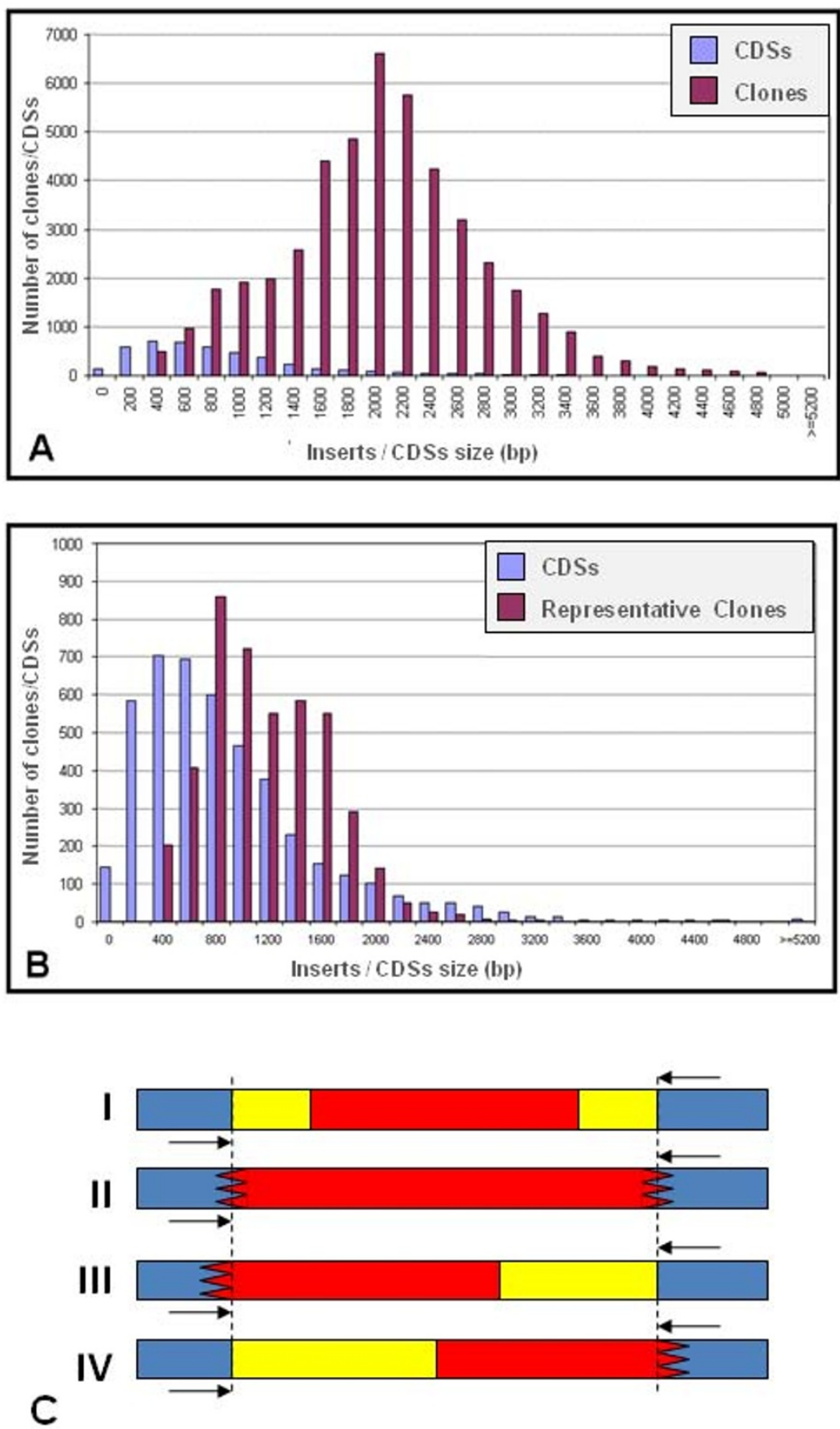

Figure 1 (A) Size distribution of the 46,462 inserts generated by the shotgun technique and of the 4,489 CDSs annotated in the XAC genome. (B) Distribution of the 4,421 selected clones, which best represented 3,084 CDSs of the XAC genome. Note in both figures that for the CDSs that were 0 to $200 \mathrm{bp}$ in length and for a small fraction of genes that were up to $400 \mathrm{bp}$ in length, representative clones were not found in the shotgun library, following the selection criteria described in the methods. (C) Representative scheme of the type of clones selected from the XAC genomic library. The blue region represents the sequence of the pUC19 cloning vector. The region marked by dotted vertical lines bounds the insert of the clone. The region where the CDSs do not overlap is marked in yellow, and the corresponding overlap is marked in red. The region with a serrated end represents the rupture of the sequence of the gene of interest. Black arrows represent the universal oligonucleotide primer (M13) used for the PCR amplification of the insert. 


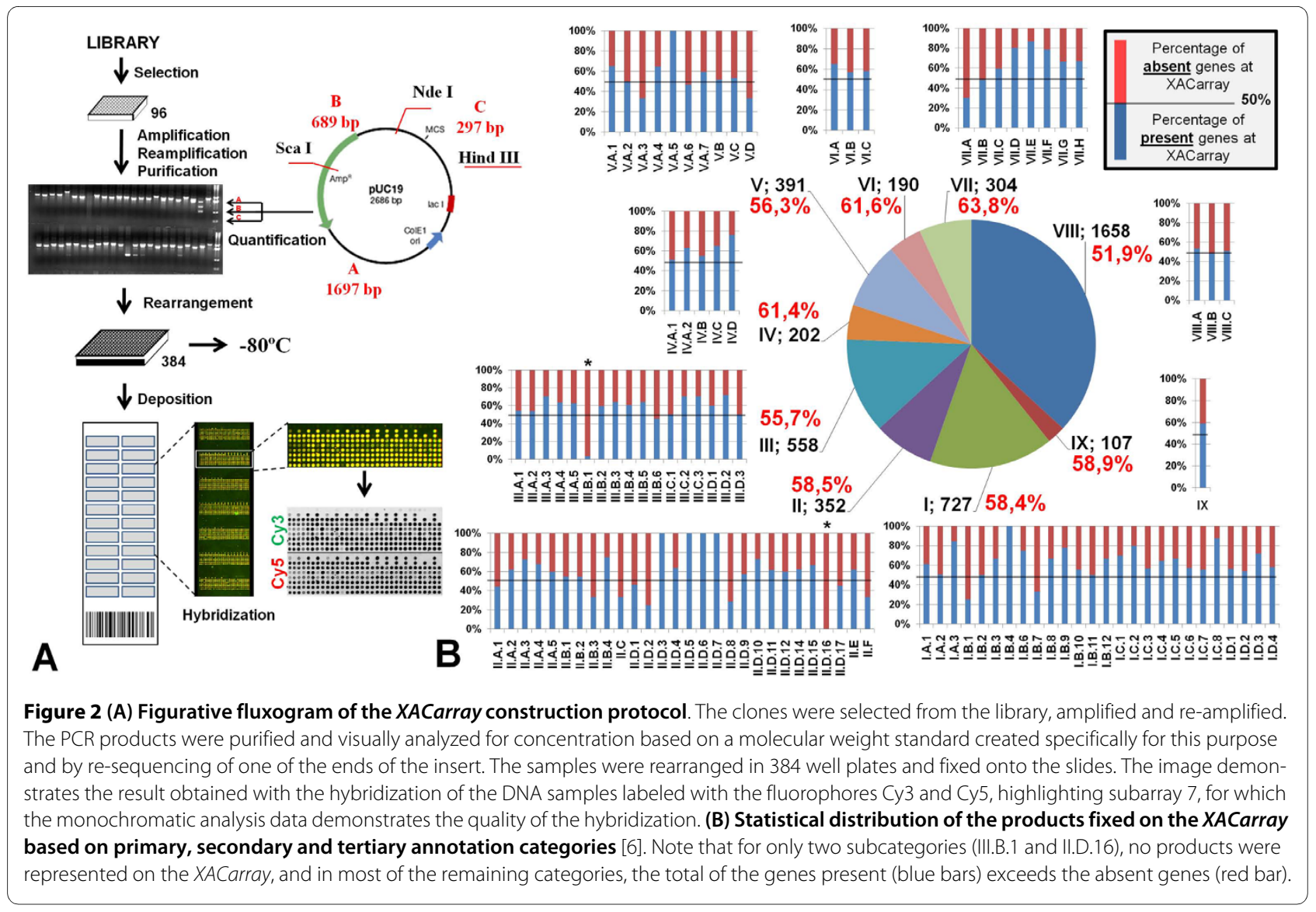

density and artifacts removal (MTM Dens). Array Vision software allowed the exclusion of bad pixels (pixels within a section that showed signal intensity either above or under four median absolute deviations (MADs) of the signal intensity of all of the pixels in the section).

\section{Results}

\section{Construction of XAC DNA microarrays (XACarray)}

The selection of clones from the XAC shotgun libraries allowed for the identification of 4,421 clones, which represented 3,084 individual CDSs of the XAC genome (Figure 1A). The remaining 1,405 CDSs, which would complete the genome, were not selected because they represented very small CDSs, smaller than $200 \mathrm{bp}$ for example (Figure 1B), or because they were not physically found in the shotgun library [6].

Table 1 and Figure $1 \mathrm{C}$ present the distribution and profile, respectively, of numbers of CDSs and selected clones, as well a schematic model of the CDS/insert overlap, which was used as a reference in the classification of the clones. It is worth noting that the ideal clones are classified as overlap type II, because the insert of these clones as a whole represents a part of the CDS of interest. Therefore, overlap of other genes or intergenic regions do not exist. However, this type of clone was the least represen- tative in the XACarray and consisted of only 292 (11.1\%) of the fixed CDSs (Table 2). For the other three types of selected clones (I, II and IV), an overlap region of other CDSs or intergenic regions with the insert was always present. Of those, the most representative overlap type was type I (see methods), totaling 1,184 fixed CDSs on the slide $(44.9 \%)$ and presenting a insert/CDS of interest ratio of 0.76 (Table 2).

After the in silico selection, the clones were rearranged in 47, 96 well plates using a Q-Bot $\operatorname{robot}^{\mathrm{m}}$ (Genetix, UK), and the inserts were amplified by PCR (see methods). Approximately $5 \%$ of the clones were shown to be not viable, and $10 \%$ presented an insert with a size different from that which was predicted (data not shown), suggesting the existence of probable errors in clone labeling, a common occurrence in clone library construction, even in commercial libraries [19]. Moreover, another $15 \%$ presented negative results with respect to their amplification. For these reasons, it was necessary to re-sequence one end of the insert of each of the previously selected clones in order to confirm the identity of all of the clones. The sequences were compared to the XAC genome, and the identity of the clones was corrected when necessary. Unfortunately, at the end of all the steps described above, approximately $30 \%$ of the initially selected clones $(1,326)$ 
Table 2: Analysis of the CDSs deposited on the XACarray based on the hybridization signal during the experimental validation of the platform.

\begin{tabular}{|c|c|c|c|c|c|c|c|}
\hline \multirow{2}{*}{$\begin{array}{l}\text { Type of } \\
\text { clones }\end{array}$} & \multicolumn{3}{|c|}{ Physical analysis (Fixed PCR products) } & \multicolumn{2}{|c|}{ Annotationc } & \multicolumn{2}{|c|}{ Hybridization signal } \\
\hline & $\begin{array}{l}\text { Clones } \\
n^{\circ}(\%)\end{array}$ & $\begin{array}{l}\text { AISa } \\
\text { (bp) }\end{array}$ & $\begin{array}{l}\text { C/lb } \\
(\%)\end{array}$ & $\begin{array}{c}\text { Function } \\
n^{\circ}(\%)\end{array}$ & $\begin{array}{c}\text { Hypothetical } \\
n^{\circ}(\%)\end{array}$ & $\begin{array}{c}\text { Function } \\
n^{\circ}(\%)\end{array}$ & $\begin{array}{c}\text { Hypothetical } \\
n^{\circ}(\%)\end{array}$ \\
\hline 1 & $1,184(57.6)$ & 1,487 & 56.8 & $631(53.2)$ & $553(46.8)$ & $574(90.9)$ & $485(87.7)$ \\
\hline ॥ & $292(63.1)$ & 1,121 & 100 & $235(80.5)$ & $57(19.5)$ & $215(91.5)$ & $52(91.2)$ \\
\hline III & $490(59.3)$ & 1,211 & 69.9 & $343(70.0)$ & $147(30.0)$ & $323(94.2)$ & $123(83.7)$ \\
\hline IV & 673 (59.9) & 1,209 & 70.5 & $466(69.2)$ & $207(30.8)$ & 436 (93.6) & $184(88.9)$ \\
\hline Total & $\begin{array}{l}2,639 \\
(59.7)\end{array}$ & 1,324 & 82.1 & $\begin{array}{l}1,675 \\
(63.5)\end{array}$ & $964(36.5)$ & $\begin{array}{l}1,521 \\
(90.8)\end{array}$ & $844(87.6)$ \\
\hline
\end{tabular}

a AIS (average of insert size).

${ }^{\mathrm{b}} \mathrm{C} / \mathrm{I}$ (average of overlapping size CDS/Insert)

cAnnotation based on Silva et al 2002 [6].

Note that the number of clones that were amplified and positively annotated represent only $59.7 \%$ of the total clones initially selected (4,421), and that 2,365 of individual CDSs presented a positive hybridization signal, which represent $52.7 \%$ of the total annotated CDSs in the genome and $89.6 \%$ of the fixed products.

could not be used. Thus, at the end of these steps, expected identity of 2,653 clones were confirmed and this set was used. They were rearranged again, now in 28 96well plates. Although the number of clones was severely reduced, the microarray contained a set of clones with a reliable identity. However, after the PCR was performed to increase the amount of the probe to be immobilized on the slides, the number of clones was reduced to 2,639, which represented $58.8 \%$ of the XAC genome (Table 2). To this set of 2,639 PCR products, 121 products derived from amplifications of genomic DNA sequences using specific oligonucleotides that were previously acquired for other experimental proposals were added; these products represented the sequences of genes of particular interest, including the genes vir, hrp, rpf and gum. Thus, the 2,760 PCR products were purified (probes), rearranged in 8384 -well plates, and used in the construction of microarrays as described above.

It is necessary to highlight that the molecular mass pattern obtained from the pUC19 plasmid not only facilitated the analysis of the amplified product, but also demonstrated that this approach was correct. The banding pattern quantification of some randomly selected PCR products corresponded to the visual quantifications that were performed using only the agarose gels (data not shown).

\section{XACarray validation}

For an initial validation of the quality of the XACarray, hybridization with XAC genomic DNA labeled with dis- tinct fluorophores was performed. Figure $2 \mathrm{~A}$ shows the fluxogram of the XACarray protocol and the hybridization images obtained using this probe. Note that the spots on the slide are practically all yellow in color, which visually represents the hybridization of probes labeled with Cy3 and Cy5 in similar quantities. This result can be observed more rigorously from the monochromatic images obtained from laser scanning at 550 and $650 \mathrm{~nm}$, respectively.

The analysis of these images revealed a noticeable signal above the background noise for $88.5 \%$ of the CDSs represented in the XACarray, a percentage that is equivalent to 2,365 individual CDSs of the XAC genome (52.7\%). Table 2 summarizes the physical features of the 2,670 probes deposited on the XACarray. The probes are represented in Figure $1 \mathrm{C}$ in relation to the type of overlap of the insert and the average size of these sequences. The classification of the CDSs regarding their annotation characteristics is shown in Table 2. The CDS are classified into two major groups: CDSs previously annotated with a determined putative function, which represent $63.5 \%$ of the XACarray; and CDSs that compose the hypothetical group, in this case exclusive hypothetical and conserved hypothetical in other organisms, which represent the other $36.5 \%$ of the composition of the array.

Quantitatively, the XACarray can be considered to be representative of the XAC genome, not only for containing probes that represent more than $50 \%$ of all XAC genes, but also for presenting $83.4 \%$ of all of its annotation categories, with more than $50 \%$ of the functionally 


\section{CHROMOSOME}

\section{XACarray GENE MAP}

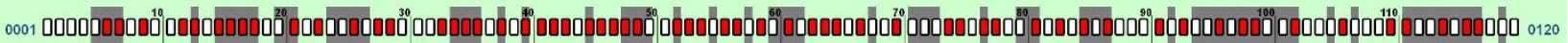

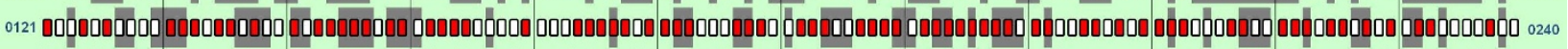

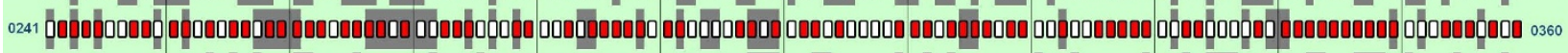

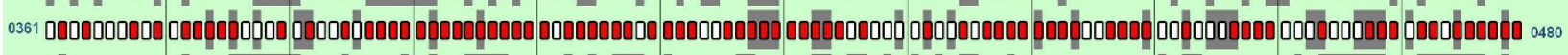

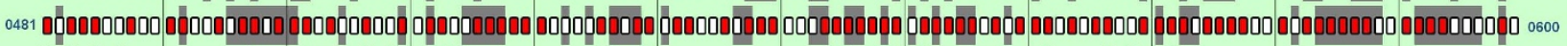

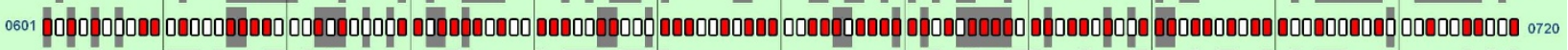

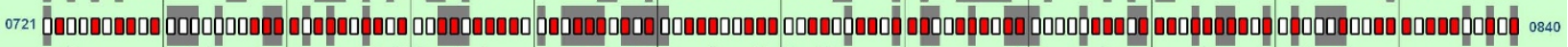

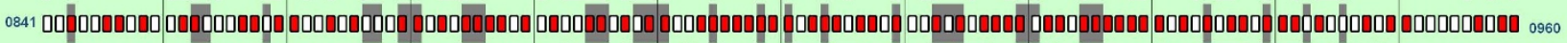

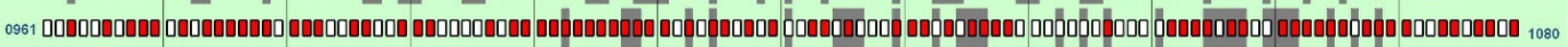

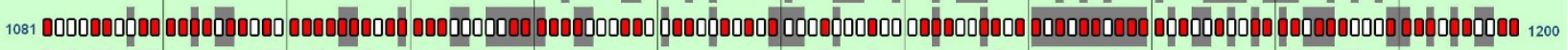

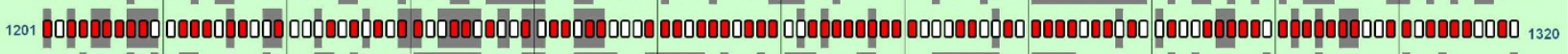

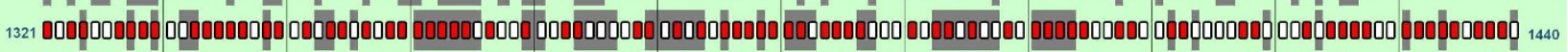

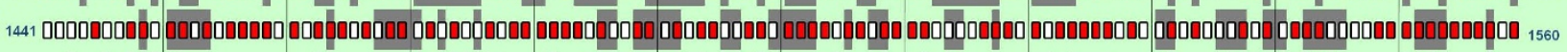

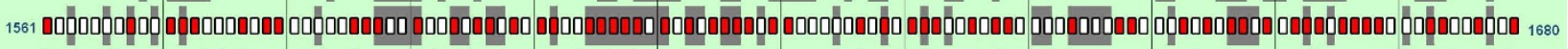

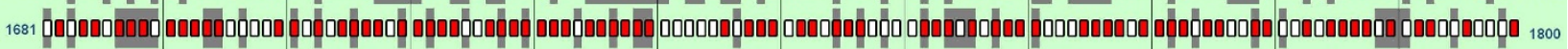

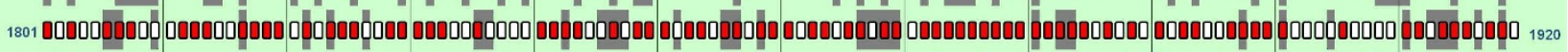

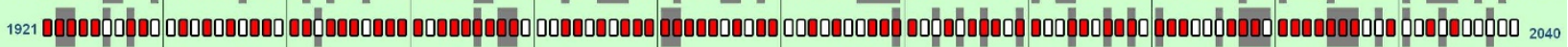

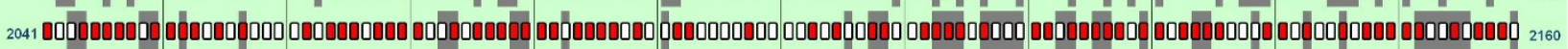

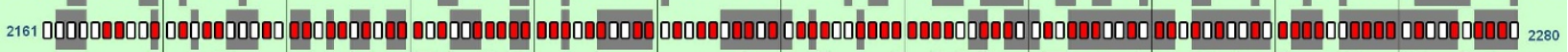

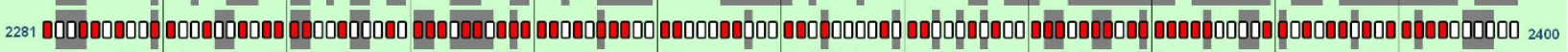

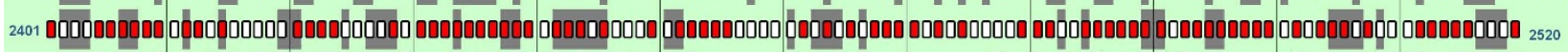

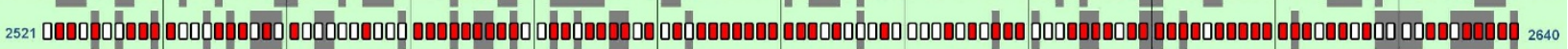

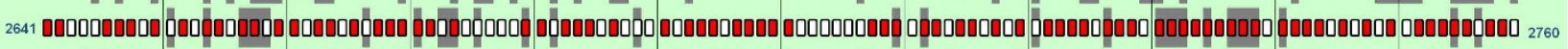

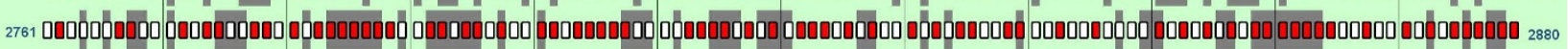

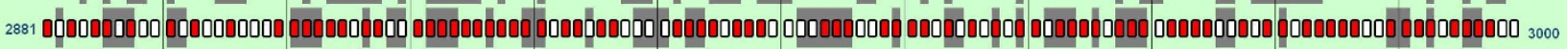

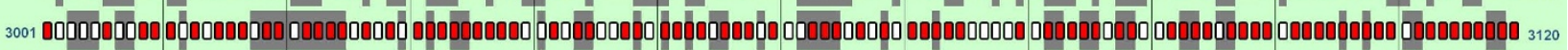

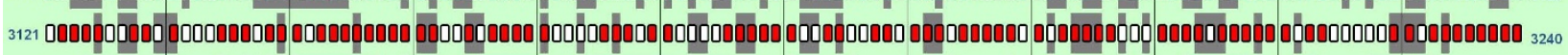

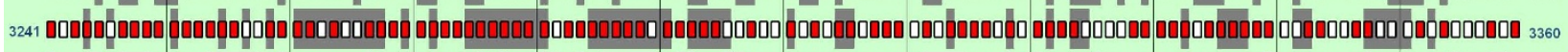

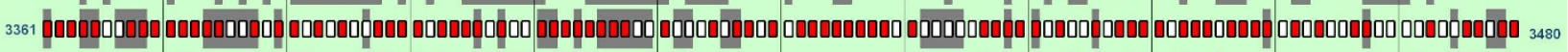

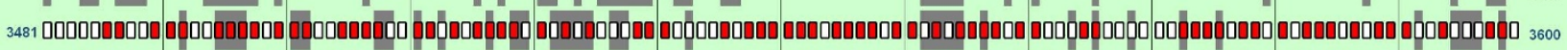

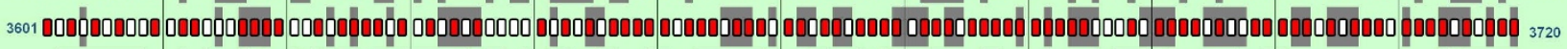

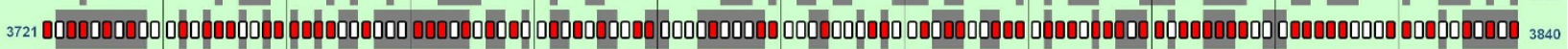

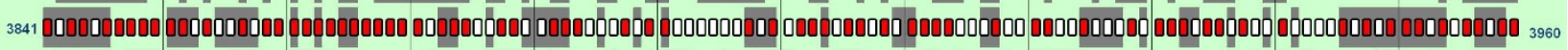

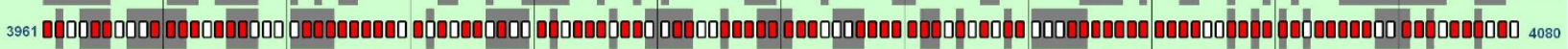

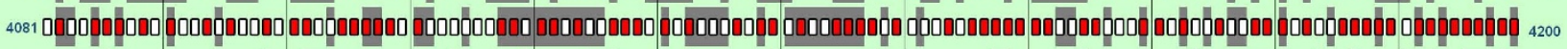

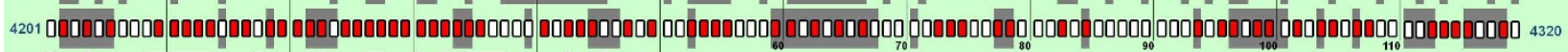

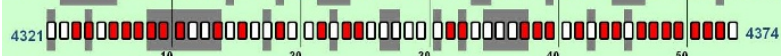

$$
\begin{aligned}
& \begin{array}{ll}
\text { PLASMID p } 33 & \text { PLASMID p64 }
\end{array}
\end{aligned}
$$

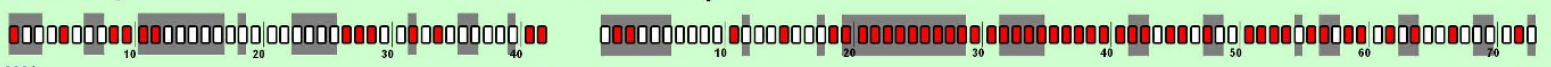

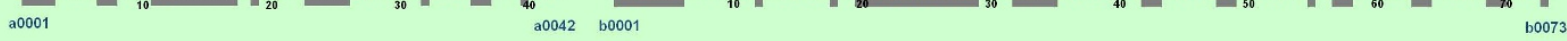

Figure 3 XAC genes presented on the XACarray. Those CDs whose products were fixed on the XACarray are marked in red (2,760 in total). The gray background highlights the genes annotated as hypothetical or hypothetical conserved. The CDS products highlighted in the figure are presented in the additional file 1 . 
annotated genes (Figure 2B). This global vision of representation can be observed in detail in Figure 3 and additional file 1, which correlates the gene map of annotations to the CDSs fixed on the slide.

\section{Conclusions}

In this study, we developed a new and low-cost method to generate a DNA microarray. Previously, Astua-Monge et al. [20] used a DNA macroarray, implemented on nylon membranes and containing probes for 279 XAC genes associated with pathogenicity and virulence, to investigate genes differentially expressed in a synthetic medium (XVM2) that simulates in planta conditions. In contrast, our plataform is the first DNA microarray platform for $\mathrm{XAC}$ that representes more than $50 \%$ of all XAC genome CDSs.

The platform was constructed from shotgun libraries, previously generated for the genomic sequencing project. Although the clones of type II are ideal, because they are restricted to include just an internal fragment of the target gene, we have made an effort to select clones that would not overlap with other genes. In our array, there are at least 1,290 clones ( $30 \%$ of the genome, not counting the ones for which specific primers were designed) that contain genome fragments that do not overlap any gene besides the target gene they were selected to represent. Also, many genes that have fragments in the same clone will correspond to operons and could, in a first crude analysis, be regarded as a single expression unit, with additional experiments clarifying which gene(s) are indeed relevant. Therefore, our platform can be used to generate lists of putative differentially expressed genes in $\mathrm{XAC}$ under different physiological conditions.

On the other hand, the presence of overlapping probes makes it necessary to subsequently validate individual candidate genes using methods with higher specificity and sensitivity, like qRT-PCR. Moreover, under most conditions, some more expensive methods, like designedprobe chips and RNA-Seq will always provide better specificity/sensitivity rates and better reproducibility and such methods should be preferred whenever researchers have access to them. Functional results using this platform were described in a recent work that use this tool to validated putative insertion/deletion regions between different and incomplete genomes sequences of other Xanthomonas species [21].

\section{Additional material} Additional file 1 Additional informations about the CDSs highlighted
in Figure 3.

\section{Competing interests}

The authors declare that they have no competing interests.

\section{Authors' contributions}

LMM: Responsible for the amplification, purification and fixation of the material onto the slides, participated in the validation of the hybridization platform, preparation of the manuscript and elaboration of all figures; MLL: Participated in the amplification reactions and in the preparation of the manuscript; RFS: Responsible for assembling the software for in silico selection of the representative clones and participated in the preparation of the manuscript; PZ: Participated in the preparation of the manuscript; ACRS: Participated in the preparation of the proposal, the construction of the shotgun libraries and the assembly of the platform itself; AMS: Participated in the project design and the data analysis; JAF: Participated in the construction of the shotgun libraries, the data analysis and the preparation of the manuscript. All authors read and approved the final manuscript.

\section{Acknowledgements}

We acknowledge the Fundação de Amparo à Pesquisa do Estado de São Paulo (FAPESP) for granting PhD scholarships to LMM, RFS, PZ and MLM and for funding the project (CAGE).

\section{Author Details}

1Departamento de Ciências Biológicas (DECBI), Instituto de Ciências Exatas e Biológicas, Universidade Federal de Ouro Preto, Campus Morro do Cruzeiro, Ouro Preto, MG, Brazil, 2 Núcleo de Pesquisas em Ciências Biológicas (NUPEB), Universidade Federal de Ouro Preto, Ouro Preto, MG, Brazil, 3ंDepartamento de Bioquímica, Instituto de Química, Universidade de São Paulo, São Paulo, SP, Brazil, ${ }^{4}$ Departamento de Engenharia Florestal, Faculdade de Ciências Agrárias, Universidade Federal dos Vales do Jequitinhonha e Mucuri, Diamantina, MG, Brazil, 5 Departamento de Tecnologia, Faculdade de Ciências Agrárias e Veterinárias de Jaboticabal, UNESP - Univ. Estadual Paulista, Jaboticabal, SP, Brazil and ${ }^{6}$ Alellyx Applied Genomics, Rua James Clerk Maxwell 320, Campinas - SP, Brazil

Received: 3 February 2010 Accepted: 27 May 2010

Published: 27 May 2010

\section{References}

1. Gottwald TR, Graham JH, Schubert TS: Citrus Canker: The Pathogen and Its Impact. APS Net: Peer-Reviewed by Plant Health Progress 2002.

2. Brunings AM, Gabriel DW: Xanthomonas citri: breaking the surface. Molecular Plant Pathology 2003, 4(3):141-157.

3. Bitancourt AA: O Cancro Cítrico. Biológico 1957, 23:110-111.

4. Schaad NW, Postnikova E, Lacy GH, Sechler A, Agarkova I, Stromberg PE, Stromberg VK, Vidaver AK: Reclassification of Xanthomonas campestris pv. citri (ex Hasse 1915) Dye 1978 forms A, B/C/D, and E as X. smithii subsp. citri (ex Hasse) sp. nov. nom. rev. comb. nov., X. fuscans subsp. aurantifolii (ex Gabriel 1989) sp. nov. nom. rev. comb. nov., and X. alfalfae subsp. citrumelo (ex Riker and Jones) Gabriel et al., $1989 \mathrm{sp}$. nov. nom. rev. comb. nov.; X. campestris pv malvacearum (ex smith 1901) Dye 1978 as X. smithii subsp. smithii nov. comb. nov. nom. nov.; X. campestris pv. alfalfae (ex Riker and Jones, 1935) dye 1978 as X. alfalfae subsp. alfalfae (ex Riker et al., 1935) sp. nov. nom. rev.; and "var. fuscans" of X. campestris pv. phaseoli (ex Smith, 1987) Dye 1978 as X. fuscans subsp. fuscans sp. nov. Syst App/Microbio/ 2005, 28(6):494-518.

5. Schaad NW, Postnikova E, Lacy G, Sechler A, Agarkova I, Stromberg PE, Stromberg VK, Vidaver AK: Emended classification of xanthomonad pathogens on citrus. Syst App/ Microbio/ 2006, 29(8):690-695.

6. da Silva AC, Ferro JA, Reinach FC, Farah CS, Furlan LR, Quaggio RB, Monteiro-Vitorello CB, Van Sluys MA, Almeida NF, Alves LM, et al: Comparison of the genomes of two Xanthomonas pathogens with differing host specificities. Nature 2002, 417(6887):459-463.

7. Moreira LM, de Souza RE, Almeida NF, Setubal JC, Oliveira JCF, Furlan LR, Ferro JA, da Silva ACR: Comparative genomics analyses of citrusassociated bacteria. Annual Review of Phytopathology 2004, 42:163-184.

8. Moreira LM, De Souza RF, Digiampietri LA, Da Silva ACR, Setubal JC: Comparative analyses of Xanthomonas and Xylella complete genomes. Omics 2005, 9(1):43-76.9.

9. Hayward RE, Derisi JL, Alfadhli S, Kaslow DC, Brown PO, Rathod PK: Shotgun DNA microarrays and stage-specific gene expression in Plasmodium falciparum malaria. Mol Microbiol 2000, 35(1):6-14.

10. Fleischmann RD, Adams MD, White O, Clayton RA, Kirkness EF, Kerlavage AR, Bult CJ, Tomb JF, Dougherty BA, Merrick JM: Whole-genome random 
sequencing and as sembly of Haem ophilus influenzae Rd. Science 1995, 269(5223):496-512.

11. Holmes DS, Quigley M: A rapid boiling method for the preparation of bacterial plasmids. Anal Biochem 1981, 114(1):193-197.

12. Raffelsberger W, Dembele D, Neubauer MG, Gottardis MM, Gronemeyer H: Quality indicators increase the reliability of microarray data. Genomics 2002, 80(4):385-394.

13. Ausubel FM, Brent R, Kingston RE, Moore DD, Seidman JG, Smith JA, Struhl K: Current protocols in Molecular Biology. 3rd edition. New York:: Greene Publishing Associates and Wiley-Interscience; 1990.

14. Sambrook J, Fritsch EF, Maniatis T: Molecular Cloning - A Laboratory Manual. 2nd edition. New York: Cold Spring Harbor Laboratory Press; 1989.

15. Altschul S, Madden T, Schaffer A, Zhang J, Zhang Z, Miller W, Lipman D: Gapped BLAST and PSI-BLAST: a new generation of protein database search programs. Nucleic Acids Research 1997, 25(17):3389-3402.

16. Diehl F, Grahlmann S, Beier M, Hoheisel JD: Manufacturing DNA microarrays of high spot homogeneity and reduced background signal. Nucleic Acids Res 2001, 29(7):E38

17. Schriefer LA, Gebauer BK, Qui LQ, Waterston RH, Wilson RK: Low pressure DNA shearing: a method for random DNA sequence analysis. Nucleic Acids Res 1990, 18(24):7455-7456.

18. Koide T, Zaini PA, Moreira LM, Vencio RZ, Matsukuma AY, Durham AM, Teixeira DC, El-Dorry H, Monteiro PB, da Silva AC, et al:: DNA microarraybased genome comparison of a pathogenic and a nonpathogenic strain of Xylella fastidiosa delineates genes important for bacterial virulence. J Bacterio/ 2004, 186(16):5442-5449.

19. Halgren RG, Fielden MR, Fong CJ, Zacharewski TR: Assessment of clone identity and sequence fidelity for 1189 IMAGE cDNA clones. Nucleic Acids Res 2001, 29(2):582-588.

20. Astua-Monge G, Freitas-Astua J, Bacocina G, Roncoletta J, Carvalho SA Machado MA: Expression Profiling of Virulence and Pathogenicity Genes of Xanthomonas axonopodis pv. citri. Journal of Bacteriology 2005, 187(3):1201-1205.

21. Moreira LM, Almeida NF Jr, Potnis N, Digiampietri LA, Adi SS, Bortolossi LC, da Silva AC, da Silva AM, de Moraes FE, Oliveira JC, de Souza RF, Fancincani $A P$, et al:: Novel insights into the genomic basis of citrus canker based on the genome sequences of two strains of Xanthomonas fuscans subsp. aurantifolii. BMC Genomics 2010, 11(1):238.

doi: 10.1186/1756-0500-3-150

Cite this article as: Moreira et al., Development and validation of a Xanthomonas axonopodis pv. citri DNA microarray platform (XACarray) generated from the shotgun libraries previously used in the sequencing of this bacterial genome BMC Research Notes 2010, 3:150

\section{Submit your next manuscript to BioMed Central} and take full advantage of:

- Convenient online submission

- Thorough peer review

- No space constraints or color figure charges

- Immediate publication on acceptance

- Inclusion in PubMed, CAS, Scopus and Google Scholar

- Research which is freely available for redistribution

Submit your manuscript at www.biomedcentral.com/submit
C Biomed Central 